\title{
The Corporate Way: Meaning and Dimensions in the Great Companies
}

\author{
Najm A. Najm ${ }^{1}$ \\ ${ }^{1}$ Department of Business Administration, Al-Zaytoonah University of Jordan, Amman, Jordan \\ Correspondence: Najm A. Najm, Department of Business Administration, Al-Zaytoonah University of Jordan, \\ Amman, 11733, PO Box 130, Jordan. E-mail: najim_abood@yahoo.com
}

Received: December 8, 2014

Accepted: December 29, $2014 \quad$ Online Published: January 4, 2015

doi:10.5430/ijba.v6n1p38

URL: http://dx.doi.org/10.5430/ijba.v6n1p38

\begin{abstract}
Great organizations such as IBM, GE, Toyota, Walt Disney, etc. developed their own ways to effectively manage their business, create high value, and achieve sustainable competitive advantage that can not be imitated by their competitors. The way is not a magical ability or miraculous phenomenon in the successful organization, but it is a managerial innovation to create a unique combination of vision, values, and practices in unique circumstances of organization. It's a corporate DNA, the dominant gens, and organization's spirit.

This paper aims to investigate the meanings, features, and functions of the organization's way and its impact on formulating and promoting its excellence and achieving outstanding results. The paper results show that there are many directions to explain the deep meaning of the way in successful organizations. Finally, some learned lessons are drawn.
\end{abstract}

Keywords: the way, corporate DNA, mental model

\section{Introduction}

Individuals develop their own ways of life and work, as well as companies work hard in a competitive context for the development of its own way in order to work efficiently and achieve superiority over its competitors. (Eisenstein, 2013, p143) believes that the way of the world is the scientific method. However, this somehow leads to the reduction of our world, which is characterized by different capacities and diverse paths, to one best way. A straight line is the shortest distance between two points, but a curve, an L-shaped path, and a Zigzag are all viable options to connect the two points. In other words, using railways is one way to get to a destination from a certain point but it is not the only way, and perhaps not always the most efficient. The way in this context is an open choice to make the potential smart available, in order to reach our goals efficiently and effectively.

\section{Concept of the Way}

Division of labor, Babbage principle, Taylor's one best way, and Ford's repetitive mass production, despite of being powerful forces for increasing productivity and economic efficiency, however this was at the cost of human dignity, and the company's ability to innovate (Pruijt, 1997, p93, Swann, 2009, p182). Division of labor and one color for all contributed for two centuries to increase productivity, but it made all factories and companies identical without soul, identity, and special imprint. For these reasons, we can say that "the way" represents a pattern of corporate thinking outside the box and restoring the spirit of the company.

The way is the equivalent of all the outstanding characteristics of the company that make it different from other companies. The way in successful and leading companies, such as IBM and Toyota, is not a case of magic or superhero phenomenon. It is however, a live and effective product that extends over many years, during which companies pass through basic stages of the organizational life cycle, including various painful failures and happy successes. More importantly, there is this "collective distinct personality" of the company and what looks like a corporate DNA that generates a particular way to be different from the ways of other companies in doing business. In other words, a company that achieves outstanding successes in a competitive market for many years has its own way that reflects its own assumptions and values in business.

This simply means that the company's excellence and all critical survival and growth factors are attributed to the company's way being the distinct personality and soul of the company. The success of a company and the failure of another, despite they are both working according to the same management principles and business rules, can be seen 
as the effect of an unknown factor (W) in realizing the corporate success. This unknown factor is in fact the company's way. Standardization of Taylorism, Fordism, McDonaldism and on the Internet Googlization, established companies of a single pattern, technology and culture in all their branches. They have succeeded due to the bigger size, the single recipe i.e. one juice for all. In contrast, other companies succeeded by diversity and their strong own way in business (see Table 1).

Table 1. Standardization and diversity (the way)

\begin{tabular}{ll}
\hline \multicolumn{1}{c}{ Standardization (one best way) } & \multicolumn{1}{c}{ Diversity (the way) } \\
\hline $\begin{array}{l}\text { Bureaucracy: tight hierarchy, solid regulations and } \\
\text { rules, predetermined and enforceable procedures. }\end{array}$ & $\begin{array}{l}\text { Organization's expertise is a significant driver to } \\
\text { develop business model. } \\
\text { Taylorism: one best way. }\end{array}$ \\
$\begin{array}{l}\text { Corporate DNA: there are no two organizations } \\
\text { identical. }\end{array}$ \\
$\begin{array}{l}\text { Fordism: standard form of mass production, } \\
\text { Inspiring corporate spirit instead of standard rules. }\end{array}$ \\
$\begin{array}{l}\text { McDonaldization: one way with culture possesses } \\
\text { the characteristics of a fast-food restaurant. }\end{array}$ & $\begin{array}{l}\text { Unique synergy: organization is a unique } \\
\text { combination of all its components. }\end{array}$ \\
$\begin{array}{l}\text { Googlization: Googlized pattern of service leads to } \\
\text { patterning our preferences and choices on Internet. }\end{array}$ & Busidiversity is a similar to biodiversity. \\
It’s a googlization meme (in Dawkin's concept). & \\
\hline
\end{tabular}

In short, there are many meanings of the way; the most important can be identified in the following:

- It is equal to a corporate's particular, special thing, and unique characteristics.

- The organization DNA.

- A company's whole.

- The company's mental model of doing business.

- Diversity of companies versus standardization of industry.

- The company's collective distinct personality from other companies.

- The unique combination of the organization's resources and capabilities.

- The spirit or the soul of company.

- The dominant gens of the company.

This implies that there are multiple ways to achieve success in business, not one way (in Frederick Taylor's language, one best way). Figure 1 shows that the alpha way for success and excellence in one company can be achieved completely differently by the beta of another company.

\section{Characteristics of a Corporate Way}

Companies that developed their own "way", managed to survive for a longer time compared to companies that have not succeeded in developing their own way. The annual reports of organizations that excel in financial indicators include the investment, financial, and technological achievements, which do not differ much from one company to another. However, in organizations that are characterized by their own way, distinctive physical indicators with a distinguished company's vision, culture and values often accompany such reports. In this context, we can refer to a number of properties of the corporate way depending on the many cases of companies characterized by having a special way to do business.

\subsection{The Ability to Find What Is Unique to the Organization's Experience}

The majority of organizations operate according to the usual common ways and often on the basis of learning from others through copying and cloning. In contrast, very few of these organizations work on the basis of a "special thing", which they see in their own way and do not see in other companies. This special thing achieves the busi-diversity in a similar manner to the biodiversity. 

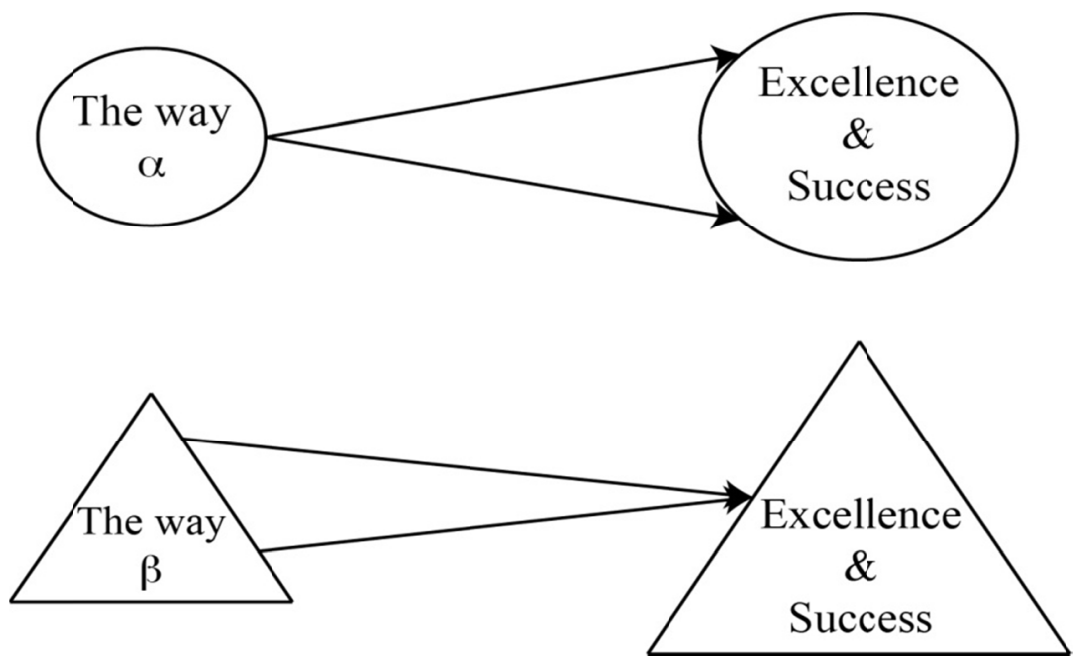

Figure 1. Different ways to excellence and success

\subsection{Individual Connection of Workers to the "Special Thing"}

The special thing cannot mean much if it remains an ideal of the organization's vision or a value of the leadership. It has to be turned into a mass vision in the organization in such a way that creates a connection between the workers and the special thing.

\subsection{Human Significance}

It is shown by numerous examples that the technological and financial capacities of an organization, as an organizational advantage, cannot maintain the superiority over competitors for a long time. This is mainly because such capacities can be developed or bought. The only sustainable competitive advantage is the one connected to human significance, and excellence of human interaction and synergy, which in contrast with technological and financial capacities, cannot be cloned.

\subsection{Unique Synergy of the Organization Compared to Competitors}

The company's capabilities, vision, field, and environment represent a unique combination that distinguishes the company from other companies operating in the same environment and field. Such distinct combination, through creative understanding and smart treatment, leads to the development of a unique synergy in the company. This synergy represents the best in inspiring the purpose and meaning, the most efficient use of resources, and achieving the highest results.

\subsection{Intelligent Listening to the Field in Which the Organization Operates}

It is the knowledge, focus, and understanding of the field in which the organization operates. In the Zen way, the truth is at your fingertips, and you have the ability to reach it (Pretiss, 2006, p13). This means that the "way" is within our ability to develop, and thus reach what it can achieve for us. For example, the most critical factor in working in areas of high altitudes is air, however in low altitudes it is humidity. This implies that the field cannot disclose its factors leading to superiority unless there is an intelligent listening and creative understanding of its characteristics. In the Walt Disney way, we find the uniqueness of the field in the dream (the desire of your heart), the magic kingdom (ultra fantasy world), everything starts with a mouse (the mouse represents life), and coloring outside the line emphasizes thinking outside the box.

\section{Developing the Way}

The development and evolution of a company's way cannot be achieved by copying others or strict adherence to business rules that are prevailing in an industry or environment. The starting point to such development is with the company sense of privacy and self-inner dimension that is the closest to the company's spirituality. Distinctive companies senses with a growing clarity, in time, that it has something to offer in a new distinct way compared to what others offer. In general, we can determine the factors required for the development of away in distinctive companies in the following: 
i. Vision: having a vision must be understood as the opposite to spontaneity, randomness and serendipity. According to (Hill and Jones, 2011, p30) vision is the desired future condition that the organization aims to achieve. Thus, an organization's vision drives the individual and the group, to do something new and to have an impact to accomplish what is called "strategic uniqueness".

ii. Passion: it is a strong desire, intense emotion, quaint aspiration toward what the organization wants to achieve. This passion feeds and strengthens the "way" of the organization, and it takes the form of a great energy in individuals who have the vision and are seeking to fulfill it with relentless determination and huge emotion that does not subside until it achieves what it seeks. In Walt Disney's way there is a dream that shines there in every idea and inspires workers to be at the level of the dream and to provide all what is necessary to achieve it.

iii. Ethics: The way does not work in vacuum, nor does it seek what cannot be accepted from the perspective of personal and organizational values. As a result, the directive "Be Ethical" is a long-term factor to keep the dream real and the passion true and renewed constantly because it derives its regeneration from right values and fair methods.

iv. Spirituality:

- It is the factor that gives a vision the reality of the ultimate purpose.

- It imparts certainty to passion that our intense emotions are going in the right direction.

- It gives ethics the highest value in sublimation to achieve additional dimensions of what is right.

v. Distinctive combination: The way is formed over time as a combination of the organization's resources and capabilities such that it uniquely distinguishes the organization from other organizations. In psychology, there are no identical personalities, regardless of how many individuals compared to find congruence or symmetry, or even the substantial convergence (Burger, 2011, p3). This is due to the fact that each personality is also a distinct combination, and in spite of the identical environment inputs, individuals will always be different. This is because every individual is a different combination of the same environmental elements, which forms a different character. It is to be aware of (whole) and not the (parts). Suppose that we have a full matchbox (with 41 sticks), the sticks represent the parts and on throwing them into a surface they can form a certain combination that is (whole). No matter how many times we repeat the experiment, of throwing the same matchsticks, we will get a different combination each time. Figure 2 shows the matchsticks experiment, and the infinite number of possibilities of such experiment where each combination is a unique distinct combination, and that for such matchbox the minimum number of combinations equals to $(41$ !). Where 41 factorial is:

$$
\begin{aligned}
& 41 !=33452526613163807108170062053440751665152000000000 \\
& 41 !=3.34525266 \times 10^{49} \approx \infty
\end{aligned}
$$

\section{The "Way" as a Mental Model}

A mental model is an individual's or a company's way to interact with individuals and objects and a perspective of the world. It is also the building block of knowledge, the principles, and the most stable rule in expressing the individual's self with other individuals, or the group's self in an organization with other organizations. Organizations that work on the basis of high competition and on-going threats develop its own way that is based on competition and conflict rather than cooperation. The transition of these organizations from competition to cooperation is always not easy and faces different obstacles. This is due to colliding with the way (the mental model) that the company adopted which shaped the company's principles, concepts, values, and traditions. Thus, changing its way (its mental model) will not happen for the sake of a new cooperation need that appeared due to some circumstances. In other words, "the way" is the corporate spirit and its culture that cannot be transferred, replicated, or globalized even in the globalization era. 


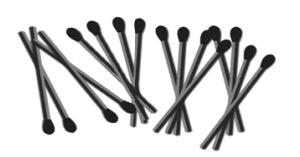

Individual

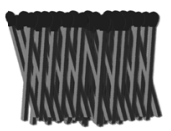

Group

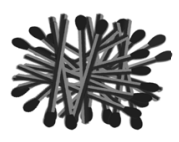

Firm $_{1}$
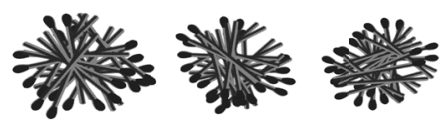

Firm $_{2}$

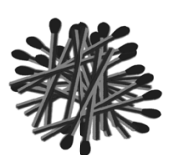

$\infty$

\section{Combinations of matchsticks}

Figure 2. Matchsticks and infinite combinations

Peter Singe (Singe, 1999) identified five characteristics of the learning organization these are: 1) systems thinking, 2) personal masterly, 3) mental models, 4) building a shared vision, and 5) team learning. The mental models represent a general frame of the company's culture and mindset. Organizations develop their own mental models during their organizational lifespans as a way to think and work in their environments. O'Brien (O'Brien, 2009, p26) emphasized that the scientific debate continues about whether human reasoning is based on mental models (as a distinct way in organization's thinking and work) versus formal rules of inference (as a scientific and rational method).

In this context, it is important to differentiate between the eastern (Asian) and the western understanding of the "way". For example, if the way in the western understanding represents the set of abstract rational rules, it is, in the eastern understanding, a way of life according to a totalitarian ethical frame that is based on the balance between the negative submission to the events and circumstances (negative submission and competence) and the absolute free well (effective competence) (Dallmayr, 2011, pp141-2). The west sees rationality as the only way and the scientific logic of thinking and problem solving. However, the east sees that one side of our problems is a result of this solid, cold, and single logic. Moreover, the east sees that there is more than one path to reach the truth just like in life where there is more than one way of thinking and working to develop and solve its problems.

In order to uncover the aspects in which the two understandings differ from each other, we note that I. Nonaka deeply revealed this in his discussion regarding (Honda) in what was later known as the "Honda Way". The Honda way unravels a unique vision that prevail Japanese companies in dealing with life, employees, and their abilities. Table 2 provides a comparison between the Honda way and the American way represented by General Motors (GM).

Table 2. The GE way versus the Honda way (Garvey, 2002, p101)

\begin{tabular}{|c|c|}
\hline GE & Honda \\
\hline People live to compete & People live to create and innovate \\
\hline Winning means everything & Life should be a joyful experience \\
\hline People are difficult to change & The potential of people is limitless \\
\hline Everything is based on winning the competition & Everything is based on finding our own purpose. \\
\hline $\begin{array}{l}\text { Knowledge production is based on comparison. Am } \\
\text { I } \backslash \text { Are we better than the others? }\end{array}$ & $\begin{array}{l}\text { Why do we exist? What is the core concept of our } \\
\text { work? }\end{array}$ \\
\hline External motivation & Knowledge production is based on self-reflection. \\
\hline Goal: to be number one & $\begin{array}{l}\text { Who am I } \backslash \text { who are we? Why do I\We want to do } \\
\text { this? }\end{array}$ \\
\hline \multirow{3}{*}{$\begin{array}{l}\text { Relation to knowledge: exploitation (using the } \\
\text { existing knowledge). }\end{array}$} & Internal motivation \\
\hline & Goal: to serve the customer \\
\hline & $\begin{array}{l}\text { Relation to knowledge: exploration (building } \\
\text { constantly new knowledge). }\end{array}$ \\
\hline
\end{tabular}

\section{The Dimensions of the Way in Distinguished Companies}

A careful review of the distinguished companies clearly shows that such companies could not have achieved superior results in their business without having their own unique distinguished way to manage their resources, culture, and 
employees. In other words, these companies have truly developed their own way that represents the best in managing their resources, abilities in their own circumstances and environments.

These distinguished companies are similar in that they all have their own unique way in doing business. This means that success has no single formula or recipe in all companies, and that the best company is the one that deduce its own combination, which conforms to its own circumstances and resources to achieve the best results possible. Table 3 presents a prompt overview of the dimensions in a set of different distinguished companies.

Table 3. The dimensions of the way in the different companies

\begin{tabular}{|c|c|}
\hline The way & The way dimensions \\
\hline The Zen Way & The human life means suffering, the purpose of human life is to be happy. The four \\
\hline Prentiss, 2006 & "Noble Truths" represent the first stage of enlightenment is to be aware that you suffer. \\
\hline Shunrya, 2010 & $\begin{array}{l}\text { The four "Noble Truths" are: Essential of life is the suffering, the origin of suffering is } \\
\text { attachment, the cessation of suffering is attainable, finding your particular path be happy. }\end{array}$ \\
\hline $\begin{array}{l}\text { The Toyota Way } \\
\text { Spear and Bowen, } \\
\text { 1999, Liker, } 2004\end{array}$ & $\begin{array}{l}\text { Long-term philosophy, the right process will create a continuous process flow to bring } \\
\text { problems to the surface, use "pull" systems to avoid overproduction, level out the } \\
\text { workload, standardized tasks and processes are the foundation for continuous } \\
\text { improvement and employee empowerment ...etc. }\end{array}$ \\
\hline $\begin{array}{l}\text { The India Way } \\
\text { Singh, } 2012\end{array}$ & $\begin{array}{l}\text { Holistic engagement with employees, improvisation and adaptability, creative value } \\
\text { propositions, broad mission and purpose }\end{array}$ \\
\hline $\begin{array}{l}\text { The GE Way } \\
\text { Magee, } 2009\end{array}$ & $\begin{array}{l}\text { Leadership is about confidence, confidently seize opportunity, strength in crisis, } \\
\text { appearances can be deceiving, understand context, cultivate big ideas, invest in } \\
\text { Innovation, use your eco-imagination, maintain core values... etc. }\end{array}$ \\
\hline $\begin{array}{l}\text { The Amazon.com } \\
\text { Way } \\
\text { Saunders, } 1999\end{array}$ & $\begin{array}{l}\text { Live and breathe E-Commerce, fill the place with entrepreneurs, focus (continues to be } \\
\text { the same), brand the site, get and keep customers by offering great value, develop } \\
\text { unbeatable logistics, stay lean, practice techno-leverage, innovation and enlightened } \\
\text { adaptation, grow with the best. }\end{array}$ \\
\hline $\begin{array}{l}\text { The Apple Way } \\
\text { Cruikshank, } 2006\end{array}$ & $\begin{array}{l}\text { Marvels and margins, find the future, take their breath away, guard the family jewels, } \\
\text { keep your promises, build the cult, get it out there, keep your cool, flog the bad guys, fix } \\
\text { your leaders, fix your plan. }\end{array}$ \\
\hline $\begin{array}{l}\text { The IBM Way } \\
\text { Rodgers, and } \\
\text { Shook, } 1986\end{array}$ & $\begin{array}{l}\text { The business and its belief, leadership, creating a totally sales-oriented environment, } \\
\text { building a super marketing organization, future-oriented marketing, solution minded } \\
\text { selling, being responsive for the customers, service orientation, measurement and } \\
\text { compensation, the entrepreneurial spirit. }\end{array}$ \\
\hline $\begin{array}{l}\text { The Bill Gates } \\
\text { way } \\
\text { Dearlove, } 1999\end{array}$ & $\begin{array}{l}\text { Be in the right place in right time, fall in love with the technology, take no prisoners, } \\
\text { hire very smart people, learn for survive, don't expect any thanks, assume the visionary } \\
\text { position, cover all the bases, build a byte-sixed business, never, ever, and take your eye } \\
\text { off the ball. }\end{array}$ \\
\hline $\begin{array}{l}\text { The Mary Kay } \\
\text { Way } \\
\text { Ash, } 2008\end{array}$ & $\begin{array}{l}\text { Golden rule leadership, you build with people, the invisible sign (every person is } \\
\text { special), praise people to success, the art of listening, be a follow-through person, } \\
\text { enthusiasm moves mountains, the speed of the leader is the speed of the gang, people } \\
\text { will support that which they help to create... etc. }\end{array}$ \\
\hline $\begin{array}{l}\text { The Pixar Way } \\
\text { Capodagli and } \\
\text { Jackson, } 2010\end{array}$ & $\begin{array}{l}\text { Remember the magic of childhood, where did the creativity go? Hey, kids: let's put on a, } \\
\text { show, dream for infinity and beyond, a new way to play "follow the leader", } \\
\text { collaboration in the sandbox, stand together against the bullies... etc. }\end{array}$ \\
\hline $\begin{array}{l}\text { The Annapolis } \\
\text { Way }\end{array}$ & $\begin{array}{l}\text { On building combat leaders, taking oaths and making commitments, follow first, The } \\
\text { crucible of character, create tri-level vision, inoculate for stress, shipmates first, success }\end{array}$ \\
\hline $\begin{array}{l}\text { Johnson, and } \\
\text { Harper, } 2005\end{array}$ & $\begin{array}{l}\text { is in the drill, lead by example, IQ is not enough, the three D's of empowerment: decide, } \\
\text { delegate, disappear. }\end{array}$ \\
\hline $\begin{array}{l}\text { The John Deere } \\
\text { Way }\end{array}$ & $\begin{array}{l}\text { Embrace the culture, quality comes first, create change through innovation, always } \\
\text { maintain integrity, commitment never quits, build a business as great as your products, }\end{array}$ \\
\hline Magee, 2005 & $\begin{array}{l}\text { put the brand to work (and protect it at all costs), all relationships must be win-win, } \\
\text { grow on the strength of your roots, performance that endures. }\end{array}$ \\
\hline $\begin{array}{l}\text { The Obama way } \\
\text { Leanne, } 2010\end{array}$ & $\begin{array}{l}\text { First, win trust and confidence, communicate your vision effectively, leverage a strong } \\
\text { reputation, make friends in unusual places, build and lead a winning team, move beyond } \\
\text { high performance to all hands, use diversity as a source of strength ... etc., }\end{array}$ \\
\hline
\end{tabular}




\section{How Do Organizations Develop Their Own Way?}

The way is a collective managerial innovation of the organization as it represents a unique combination of the human (leadership, professionals, and workers), financial, technological, and other intangible resources, the materials used, the external environment (private and public factors) that the company works and interacts with throughout its organizational life cycles. This innovation along with the unique vision of the leadership develops the sense of "the way" in thinking and working. Although organizations start their business without a definite guarantee of their success (existence and growth), there is also no definite guarantee that the organization can develop its own way. In reality, most organizations work without having their own unique way that differentiates them from other organizations (competitors or non-competitors). They all work depending on a vast set of concepts, principles, and rules prevalent in the business environment. The question here is why? The answer to this question is simply that not all organizations are innovative and "the way" mentioned in this context is a pure managerial innovation in developing and extrapolating the unique combination in the company.

Organizations' attempts to develop their own "ways" as a best response to their resources, workers, and environment provide suitable expertise to help answering how organizations can develop their own way, while taking into consideration that there is no trusted ready-made recipe for success in this case, and that it is beneficial for guidance not for strict application. The way is not a specified programme or golden rules that can be applied in all circumstances and yield results in definite success. In fact it is the most successful way in any organization that cannot be adopted by other organizations, and such adoption can be the reason for definite failure due to the difference of resources, workers, and circumstances. The only thing that other organizations can do toward such successful way, is to understand the lessons learned from it for guidance and to benefit from it without falling into the trap of blind imitation

\section{Discussion}

Outstanding individuals have their way of managing themselves. (Drucker, 1999, p163) emphasizes that history's greatest achievers, such as Napoleon, da Vinci, Mozart, have always managed themselves, and to a large extent this unique "way" of management is what makes them great achievers. Similarly, distinguished companies have their own way of managing their resources, and priorities. Additionally, (Kanter, 2011, p7) mentioned that alongside economic or financial logic, there is an institutional logic (the company's own "way") that essentially contributes to guiding principles in research, analysis, education, policy, and managerial decision making.

The way, from distinguished companies perspective, represents a managerial innovation that is of no less importance and value to the company's success than technological innovation. They both aid in improving productivity, performance, and achieving a competitive advantage that allow the company to survive and grow in the market. A difference between the two however, is that technological innovation can often be copied and replicated, however, the way cannot. This is mainly due to "the way" being linked to how individuals work, their values, and their own preferences that is most compatible with their resources and work conditions.

Though, the way has its own issues which can play a negative role in the company, this means that "the way" is not free or without burdens. The following are the most relevant issues:

a. "The way" and the single method: in a competitive business environment, the way can mean that the company is competing in one common way. In a fast paced environment, where competitors come up with different methods and work with different visions in correspondence to these changes, "the way" can become a constraint that limits the company's ability to quickly respond outside "the way" which is based on rules and dimensions that cannot be skipped without surpassing "the way".

b. Management from the grave: a powerful founder, who develops his own way that leads to a company's success, may adopt different rules, and take many actions that allow "the way" to work even after the founder has disappeared. This is often acceptable in stable environments that do not involve fierce competition. However, with competition that involves intelligent competitors who are hard working on new competitive ways, the old way, which is governed by rigid rules, can mean inflexibility and inability of the company to work and respond to competitors' challenges.

c. The mental model constraints: the way may seem in some special cases as a mental model of thinking and working that originates in both individuals and company's rules and behaviours. This may prevent the rules and principles of rational thinking from working in another way even though in some cases the other way can be more rational and efficient. (O'Brien, 2009, p96) emphasized that a mental model founds a problem that relates to whether reasoning is based on a mental model (as a common way of thinking and behaviour) 
or on formal (logical) rules of inference. This means that the way, by strict adoption or habituation, may replace rational thinking in decision and action.

d. Although the variety of ways in companies and the variety of dimensions of these ways enrich business concepts and practices that can achieve success. However, it raises a serious problem of knowledge in business where a specific dimension can be part of the success factors in a company, while an opposite dimension can be part of the success factors of another.

\section{References}

Ash, Mary Kay. (2008). The Mary Kay way: timeless principles from America's greatest woman entrepreneur. Hoboken: John Wiley \& Sons, Inc. http://dx.doi.org/10.1002/9781118257937

Bayda, E. (2010). Beyond Happiness: The Zen Way to True Contentment. Boston: Shambhala.

Burger, J. M. (2011). Personality, Wadsworth. Mason: Cengage Learning.

Capodagli, B., \& Jackson, L. (2010). Innovate The Pixar Way. New York: McGraw-Hill.

Cruikshank, J.L. (2006). The Apple Way. New York: McGraw-Hill.

Dallmayr, F. (2011). Return to Nature? Kentucky: The University Press of Kentucky.

Dearlove, D. (1999). Business the Bill Gates Way. Oxford: Capstone Publishing.

Eisenstein, C. (2013). The Ascent of Humanity: Civilization and the Human Sense of Self. Berkeley: Evolver Editions.

Garvey, B., \& Williamson, B. (2002). Beyond Knowledge Management. Harlow: Pearson Education Limited.

Grunden, N. (2008). Pittsburgh Way to Efficient Healthcare: Improving Patient Care Using Toyota-based Methods. New York: CRC Press.

Hill, C. W. L., \& Jones, G.R. (2011). Essentials of Strategic Management. Mason: Cengage Learning.

Johnson, W. B., \& Harper, G. P. (2005). Becoming a Leader the Annapolis Way: 12 Combat Lessons from the Navy's Leadership Laboratory. New York: McGraw-Hill Professional.

Kanter, R.M. (2011). How Great Companies Think Differently. Boston: Harvard Business Review, Nov 2-11.

Leanne, S. (2010). Leadership: The Barak Obama Way. New York: McGraw-Hill.

Liker, J. K. (2004). The Toyota Way: 14 Management Principles from the World's Greatest Manufacturer. New York: McGraw-Hill.

Magee, D. (2005). The John Deer Way. New Jersey: McGraw-Hill.

Magee, D. (2009). The Jeff Immelt and the New GE Way. New York: McGraw-Hill.

O’Brien, D. (2009). Human reasoning includes a mental logic. Behavioral and Brain Sciences, 32(1), 96-97. http://dx.doi.org/10.1017/S0140525X09000429

Prentiss, Chris. (2006). Zen and the Art of Happiness. California: Power Press.

Prujit, Has D. (1997). Job Design and Technology: Taylorism vs Anti-Taylorism. London: Routledge.

Rodgers, B., \& Shook, R. L. (1986). The IBM Way. New York: Harper Collins Publishers.

Saunders, R. (1999). Business the Amazon.com Way: Secrets of the World's Most Astonishing Web Business Big Shots. Oxford: Capstone Publishing Ltd.

Shunrya, Z. (2010). Zen Mind, Beginner's Mind. Boston: Shambhala Publication, Inc.

Singe, P. M. (1990). The Fifth Discipline. London: Century Business.

Singh, N. K. (2012). Eastern and Cross Cultural management. India: Springer. http://dx.doi.org/10.1007/978-81-322-0472-5

Spear, S., \& Bowen, H.K. (1999). Decoding the DNA of the Toyota Production System. Boston: Harvard Business Review, Sep-Oct, 97-106.

Swann, G. M. P. (2009). The Economics of Innovation. Cheltenham: Edward Elgar Publishing. 